\title{
Oedema in Rheumatoid Arthritis: Changes in the Coefficient of Capillary Filtration
}

\author{
MALCOLM I. V. JAYSON, JENNY S. BARKS
}

British Alcdical fournal, 1971, 2, 555-557

\section{Summary}

The rate of formation of tissue fluid for a given increase of venous pressure and for a known volume of tissue has been measured in the forearm. There is a significant increase in this figure in rheumatoid arthritis and a still greater increase in patients who develop recurrent oedema. This increase could not be attributed to steroid or phenylbutazone therapy, nor to a fall in the serum albumin. The results imply that there is some generalized abnormality in capillary function in rheumatoid disease and that this change is not limited to the joints.

\section{Introduction}

Recurrent oedema of the lower limbs is often found in association with rheumatoid arthritis. In some cases it develops around an acutely inflamed joint such as the ankle, but in many instances there is no clearly defined cause. In this study measurements have been made of an index of capillary filtration in order to define an abnormality of capillary function.

\section{Coefficient of Capillary Filtration}

Movement of fluid across the capillary membrane depends on the hydrostatic and osmotic forces first described by Starling (1896) and subsequently verified by Landis (1934) and Pappenheimer (1953). At the arteriolar end of the capillary the pressure is considerably higher than that of the interstitial tissue, so that fluid passes from within the capillary lumen into the tissue spaces. The osmotic pressure of this fluid is low because large molecular weight proteins are unable to cross the capillary wall. At the venular end of the capillary the hydrostatic pressure is much lower, and because of the relatively high osmotic pressure within the capillary lumen the fluid is therefore sucked back. There is normally a state of dynamic equilibrium between transudation and the sum of reabsorption and clearance of excess fluid into the lymphatics, so that excess tissuc fluid and frank oedema do not appear. Increase of the venous pressure will therefore upset the balance and lead to an accumulation of fluid in the tissue spaces. When measurement is made of the volume of transudate for a given pressure increase over a known period of time for a known volume of tissue then the coefficient of capillary filtration can be expressed in $\mathrm{ml} / \mathrm{min} / \mathrm{mm} \mathrm{Hg} / 100 \mathrm{ml}$.

\section{Subjects Studied}

Measurements of the coefficient of capillary filtration were obtained from 19 healthy control subjects, 15 patients with definite or classical rheumatoid arthritis (Ropes, Bennett,

Cobb, Jacox, and Jesser, 1959) and no history of oedema, and 17 patients with definite or classical rheumatoid arthritis and a history of recurrent bilateral oedema of the lower limbs without any cardiac, renal, or other identifiable cause.

\section{Experimental Method}

A segment of the forearm $12 \mathrm{~cm}$ long was enclosed within a distensible rubber sleeve and secured within a plethysmograph by upper and lower flanges (Fig. 1). Care was taken to ensure that neither the elbow nor the wrist joint would be included within the measured segment. The plethysmograph was filled with water at $34^{\circ} \mathrm{C}$, and this temperature was maintained by water circulated through a separate coil from a temperature-controlled water-bath. Volume change of the segment displaced an equivalent volume of water into an electrical resistance transducer on the upper surface of the plethysmograph and was recorded. Calibration of the transducer by injecting known volumes of fluid into the plethysmo-
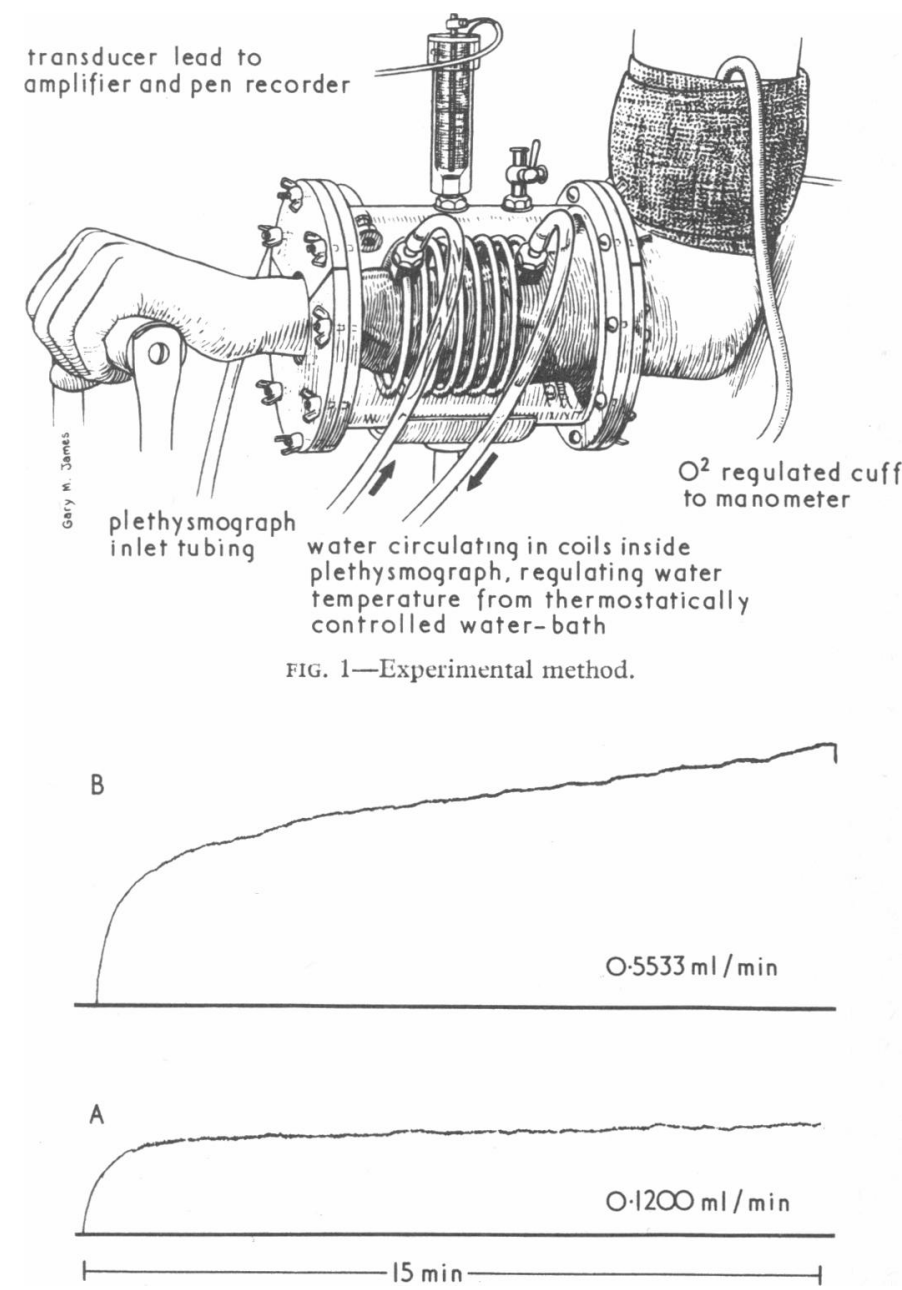

FIG. 2-Traces from rheumatoid subject with proximal cuff $\mathrm{A}$ at $30 \mathrm{~mm} \mathrm{Hg}$ and $\mathrm{B}$ at $60 \mathrm{~mm} \mathrm{Hg}$. 
graph was performed before and after every cxperiment. Throughout the study the subject gripped an appropriately placed handle so as to minimize any movement of the forearm. A large sphygmomanometer thigh cuff was wrapped around the upper arm as close to the plethysmograph as possible. The air pressure within the cuff was carefully controlled and measured with a mercury manometer.

The subject lay comfortably on a couch, and after scveral minutes the cuff pressure was suddenly raised to $30 \mathrm{~mm} \mathrm{Hg}$ and maintained at this level for 15 minutes. Constant recordings were made throughout. The cuff pressure was then released and after a further five minutes was reapplied at $60 \mathrm{~mm} \mathrm{Hg}$ for a further 15 minutes. At the end of the experiment the volume of the limb segment was calculated by subtracting the volume of water present in the plethysmograph from the known total volume of the instrument.

Typical traces obtained from a rheumatoid subject without ocdema at 30 and $60 \mathrm{~mm} \mathrm{Hg}$ are shown in Fig. 2. The initial sharp upstroke is due to venous filling, but the subsequently slow but steady rise is due to transudation. The slopes at each of these two pressures are measured and the correction described by Celander and Mårild (1962) is applied so as to obtain the capillary filtration rate at each pressure. The differcnce between the two slopes therefore gives the difference in capillary filtration due to a pressure difference of $30 \mathrm{~mm} \mathrm{Hg}$. Dividing by 30 and by the volume of the limb gives the coefficient of capillary filtration.

The total serum proteins were measured by determining the optical density at $210 \mathrm{~nm}$ and the serum albumin on the autoanalyser by the brom-cresol-green method. In several subjects it was possible to obtain specimens of oedema fluid by drainage through Southey's tubes and the oedema fluid proteins were measured.

\section{Results}

The values obtained for the coefficient of capillary filtration were similar for both sexes but there was an increase with the subject's age (Fig. 3). This age change, however, was very small when compared with the differences between these results and those from the two groups of patients with rheumatoid arthritis. Each group was therefore treated as a whole.

The mean coefficient of capillary filtration obtained for the controls was $0.0028 \pm 0.0006 \mathrm{ml} / \mathrm{min} / \mathrm{mm} \mathrm{Hg} / 100 \mathrm{ml}$, for the rheumatoids without oedema $0.0042+0.0007 \mathrm{ml} / \mathrm{min} / \mathrm{mm}$ $\mathrm{Hg} / 100 \mathrm{ml}$, and for the rheumatoids with oedema $0.0052 \pm 0.0011$ $\mathrm{ml} / \mathrm{min} / \mathrm{mm} \mathrm{Hg} / 100 \mathrm{ml}$ (Fig. 4). The differences between these three groups were statistically highly significant.

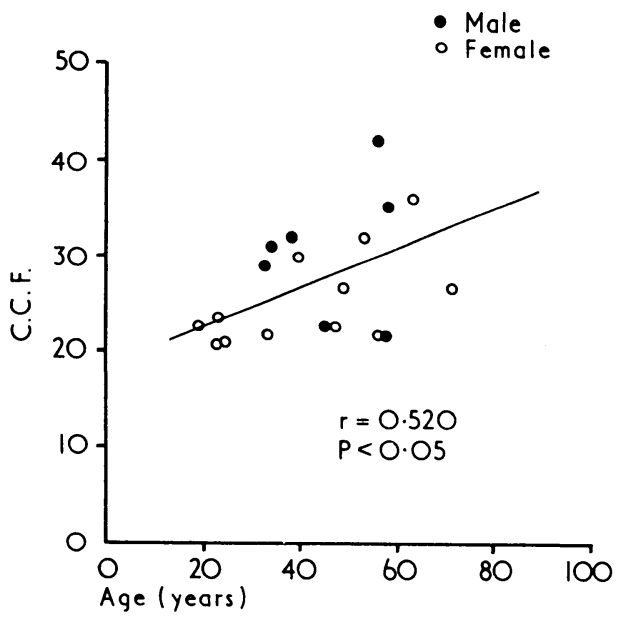

FIG. 3-Correlation of the coefficient of capillary filtration $\left(\mathrm{ml} / \mathrm{min} / \mathrm{mm} \mathrm{Hg} / 100 \mathrm{ml} \therefore 10^{\prime}\right)$ with age (ycars) for control subjects.

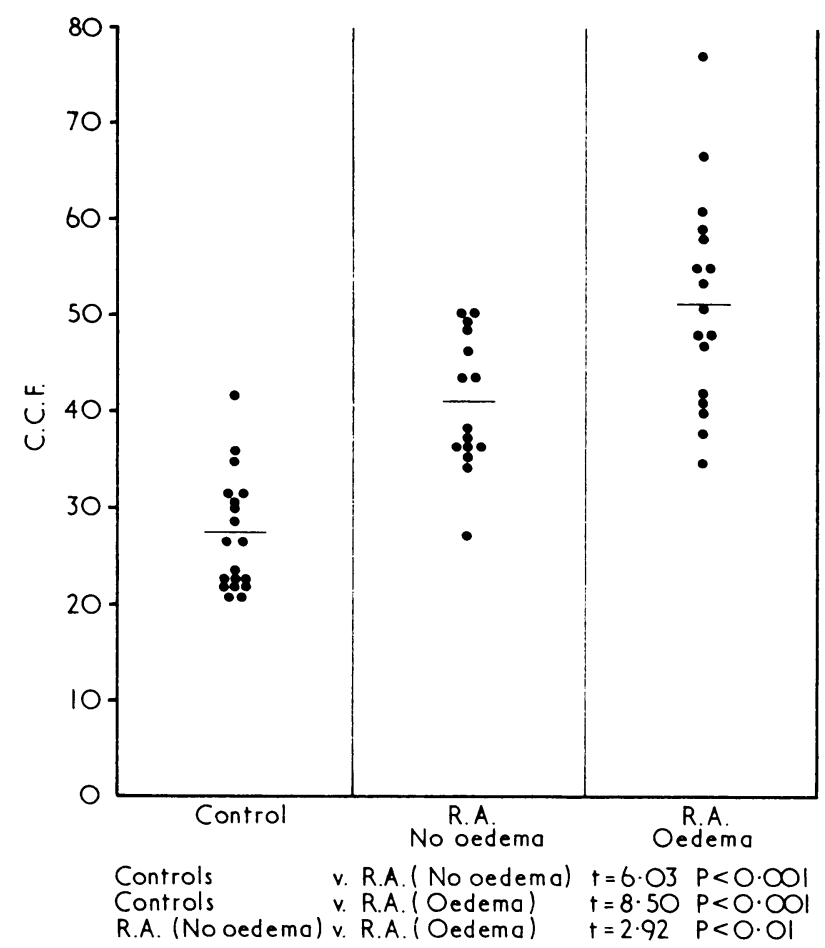

FIG. 4-Values for the coefficient of capillary filtration $(\mathrm{ml} / \mathrm{min} / \mathrm{mm}$ $\mathrm{Hg} / 100 \mathrm{ml} \cdot 10^{4}$ ) in control and rheumatoid subjects with and without oedema.

Increase in the coefficient of capillary filtration in rheumatoid arthritis could not be attributed to either steroid or phenylbutazone therapy (Table I). There was, however, a correlation of statistical significance with the blood sedimentation rate.

TABLE 1-Effect of Phenylbutazone or Steroid

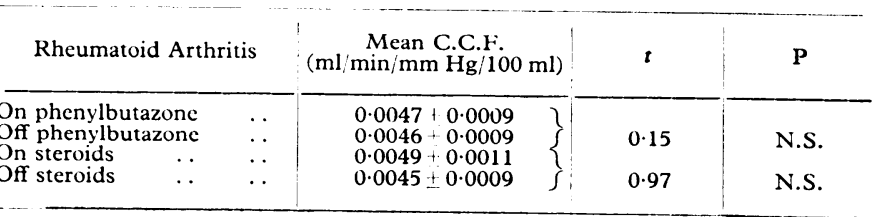

C.C.F. $=$ Cocfficient of capillary filtration.

N.S. = Not significant.

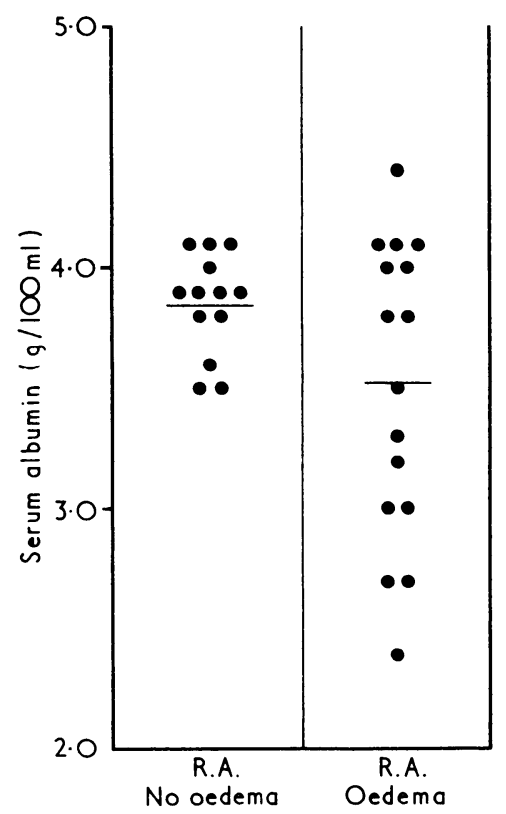

Flg. 5-Scrum albumin $(\mathrm{g} / 100 \mathrm{ml})$ in rheumatoid subjects with and without ocdema $(t=1.89 ; P>0.05)$. 
Though the mean serum albumin was lower in the oedema group than in the rheumatoids without oedema, the difference was not of statistical significance (Fig. 5). The lowest serum albumin recorded was $2.4 \mathrm{~g} / 100 \mathrm{ml}$.

Oedema fluid was obtained for analysis from five patients. The total protein levels are shown in Table II.

TABLE II-Protein Levels

\begin{tabular}{|c|c|c|c|c|c|}
\hline \multirow{2}{*}{$\begin{array}{l}\text { Case } \\
\text { No. }\end{array}$} & \multirow{2}{*}{$\begin{array}{c}\text { Ocdcma } \\
\text { Protcins } \\
\text { (g 100 ml) }\end{array}$} & \multicolumn{3}{|c|}{ Scrum Protcins ( $100 \mathrm{ml}$ ) } & \multirow{2}{*}{$\underset{(\mathrm{ml} / \mathrm{min} / \mathrm{mm}}{\mathrm{Hg} 100 \mathrm{ml})}$} \\
\hline & & 'lotal & Albumin & Globulin & \\
\hline $\begin{array}{l}1 \\
2 \\
3 \\
4 \\
5\end{array}$ & $\begin{array}{l}0.36 \\
0.42 \\
0.98 \\
1.28 \\
1.15\end{array}$ & $\begin{array}{l}6.2 \\
6.7 \\
8.0 \\
7.5 \\
7.0\end{array}$ & $\begin{array}{l}2.4 \\
3.8 \\
4 \cdot 4 \\
3.0 \\
2.7\end{array}$ & $\begin{array}{l}3.8 \\
2.9 \\
3.6 \\
4.5 \\
4.3\end{array}$ & $\begin{array}{l}0.0067 \\
0.0048 \\
0.0038 \\
0.0047 \\
0.0077\end{array}$ \\
\hline
\end{tabular}

\section{Discussion}

There are many possible mechanisms involved in the production of ocdema in association with rheumatoid arthritis. Nevertheless, no consistent abnormality has been previously described which could be responsible for production of excess interstitial fluid.

The syndrome of acute joint rupture has been described with reference to the knee, wrist (Jayson, Swannell, Kirk, and Dixon, 1969), and elbow (Goode, 1968). Synovial fluid is released into the soft tissue producing an acute inflammatory reaction and oedema formation. This syndrome, however, usually starts suddenly and the changes are limited to the particular limb involved. Continuous bilateral oedema would be unlikely to develop by this mechanism. Lymphatic obstruction by enlarged glands has been postulated as the cause (Kalliomäki and Vastamäki, 1968). However, though Robertson, Hart, White, Nuki, and Boardman (1968) confirmed that lymphadenopathy was common, they found no evidence of lymphangiectasis or lymphatic blockage. Tense popliteal cysts often develop as a result of rheumatoid arthritis involving the knee (Jayson and Dixon, 1970) and could theoretically produce venous obstruction. This may be a possible mechanism in some patients, but measurements of the venous pressure in the lower limbs have failed to reveal any change with alteration in the volume of the cyst contents (Jayson, unpublished observations).

Conflicting evidence is available about the protein content of the oedema fluid in rheumatoid arthritis. Park and Swinburne (1964) and Swinburne (1964) found the protein content to be less than $1 \mathrm{~g} / 100 \mathrm{ml}$, with a relative increase in the concentration of small protein molecules and a fall in that of the larger protein molecules. The results suggested that in rheumatoid arthritis the capillary endothelium has a normal selective permeability and that the fluid is not of inflammatory or of allergic origin, but is due to some alteration in venous function. On the other hand, Gandy, Ansell, and Bywaters (1965) and Consden and Smith (1965) found the concentrations of protein on oedema fluid to be relatively high, especially in active discase, and that in active arthritis the differential protein pattern accorded much closer to that of the serum than in inactive discase. They therefore concluded that the ocdema could be due to inflammation. Only five measurements of oedema fluid protein concentration were performed in the present study but in two of these values of over $1 \mathrm{~g} / 100$ $\mathrm{ml}$ were obtained. This figure divides low from high protein ocdemas (Crockett, 1956) and values above this imply either increased capillary permeability to protein or delayed clearance into the lymphatic system.

The critical level of serum albumin below which oedema develops is usually quoted as $2 \mathrm{~g} 100 \mathrm{ml}$ (Le Quesne, 1963). All the patients in the present series had serum albumins above this figure and the concentrations were similar in those with or without oedema. It is therefore unlikely that the scrum albumin plays a significant part in producing of this type of oedema.

The values for the coefficient of capillary filtration in the control subjects compare favourably with those reported by Krogh, Landis, and Turner (1932), Landis and Gibbon (1933), and Kitchin (1963). There is a moderate increase in the coefficient of capillary filtration in patients with rheumatoid arthritis and a still greater increase in those who develop oedema. This suggests that in rheumatoid tissue there is more rapid production of interstitial fluid than in normal tissue. When this fluid is equally rapidly reabsorbed either into the capillaries or into the lymphatic system, there is no net increase in the total volume of fluid present in the tissues and no oedema. Jue, Entrup, Hughes, Narang, and Wégria (1970), however, showed that if the capillary filtration rate is sufficiently increased then there can be a relative insufficiency of interstitial fluid evacuation. In such circumstances oedema would appear.

The experimental results indicate that in rheumatoid arthritis there is a generalized increase in the capillary filtration rate and that this could be correlated with the blood sedimentation rate. Though both steroids and phenylbutazone are associated with fluid retention, their use could not be associated with alteration in the coefficient of capillary filtration. They were not used more frequently in the patients developing oedema.

Increase in the coefficient of capillary filtration could be due either to an increase in the porosity of the capillaries or to an increase in the functional capillary surface area. The experiments were performed on the forearms with careful exclusion of any joint, and therefore of any inflamed synovium. Some generalized capillary defect must therefore be present. Such changes have already been observed in nail-bed capillaries (Redisch, Messina, Hughes, and McEwen, 1970). The oedema fluid proteins are often low, so that in these cases it would appear that the defect is an increase in functional surface area.

We thank Drs. J. Cosh, A. St. J. Dixon, and G. D. Kersley for allowing us to examine patients under their care and Mr. Alan Preece for construction of the plethysmograph. The serum proteins were kindly measured by Dr. C. Hobbs. This work was supported by grants from the Medical Research Council and the Association of Friends of the Royal National Hospital for Rheumatic Diseases.

\section{References}

Celander, O., and Märild, K. (1962). Acta Pacdiatrica, 51, 385.

Consden, R., and Smith, M. (1965). Annals of the Rheumatic Discases, 24, 239.

Crockett, D. J. (1956). Lancet, 2, 1179.

Gandy, R. H., Ansell, B. M., and Bywaters, E. G. L. (1965). Annals of the Rheumatic Diseases, 24, 234.

Goode, J. D. (1968). Annals of the Rheumatic Diseases, 27, 604.

Jayson, M. I. V., and Dixon, A. St. J. (1970). Annals of the Rheumatic Diseases, $29,415$.

Jayson, M. I. V., Swannell, A. J., Kirk, J. A., and Dixon, A. St. J. (1969). Annals of Physical Medicine, 10, 175.

Juc, J., Entrup, R. W., Hughes, M., Narang, G., and Wégria, R. (1970). American fournal of Physiology, 218, 1003

Kalliomäki, J. L., and Vastamäki, M. (1968). Annals of the Rhcumatic Diseases, $27,167$.

Kitchin, A. H. (1963). British Medical Bulletin, 19, 155.

Krogh, A., Landis, E. M., and Turner, A. H. (1932). Fournal of Clinical Investigation, 11, 63

Landis, E. M. (1934). Physiological Reviews, 14, 404

Landis, E. M., and Gibbon, J. H. (1933). Fournal of Clinical Invcstigation,

12, 105.
Lc Quesne, L. P. (1963). In Clinical Physiology, ed. E. J. M. Campbell, C. J. Dickinson, and J. D. H. Slater. Oxford, Blackwell.

C. J. Dickinson, and J. D. H. Slater. Oxford, Blackwell.
Pappenheimer, J. R. (1953). Physiologicai Reviews, 33, 387.

Pappenheimer, J. R. (1953). Physiologicai Reviews, 33, 387.
Park, D. C., and Swinburne, K. (1964). British Medical fournal, 1, 86.

Park, D. C., and Swinburne, K. (1964). British Medical Fournal, 1, 86 . of the Rheumatic Diseases, 29, 244.
.

Robertson, M. D. J., Hart, F. D., White, W. F., Nuki, G., and Boardman, P. L. (1968). Annals of the Rheumatic Diseases, 27, 253.

Ropes, M. W., Bennett, G. A., Cobb, S., Jacox, R., and Jessar, R. A. (1959). Annals of the Rheumatic Diseases, 18, 49

Starling, E. H. (1896). Lancet, 1, 1267, 1331, 1407.

Swinburnc, K. (1964). British Medical fournal, 1, 1541. 